\title{
New aerosol particle formation in different synoptic situations at Hyytiälä, Southern Finland
}

\author{
By L. SOGACHEVA ${ }^{1 *}$, L. SAUKKONEN ${ }^{2}$, E. D. NILSSON ${ }^{3}$, M. DAL MASO ${ }^{1}$, DAVID M. \\ SCHULTZ ${ }^{1,2}$, G. DE LEEU W ${ }^{1,2}$ and M. KULM ALA ${ }^{1}, \quad{ }^{1}$ Division of Atmospheric Sciences and Geophysics, \\ Department of Physics, University of Helsinki, PO Box 64, FIN-00014, Helsinki, Finland; ${ }^{2}$ Finnish Meteorological \\ Institute, PO Box 503, FI-00101, Helsinki, Finland; ${ }^{3}$ Department of Applied Environmental Science, Stockholm \\ University, 10691 Stockholm, Sweden
}

(Manuscript received 23 October 2007; in final form 24 April 2008)

\begin{abstract}
We examine the meteorological conditions favourable for new particle formation as a contribution to clarifying the responsible processes. Synoptic weather maps and satellite images over Southern Finland for 2003-2005 were examined, focusing mainly on air mass types, atmospheric frontal passages, and cloudiness. Arctic air masses are most favourable for new aerosol particle formation in the boreal forest. New particle formation tends to occur on days after passage of a cold front and on days without frontal passages. Cloudiness, often associated with frontal passages, decreases the amount of solar radiation, reducing the growth of new particles. When cloud cover exceeds $3-4$ octas, particle formation proceeds at a slower rate or does not occur at all. During 2003-2005, the conditions that favour particle formation at Hyytiälä (Arctic air mass, post-cold-frontal passage or no frontal passage and cloudiness less than 3-4 octas) occur on 198 d. On 105 (57\%) of those days, new particle formation occurred, indicating that these meteorological conditions alone can favour, but are not sufficient for, new particle formation and growth. In contrast, $53 \mathrm{~d}(28 \%)$ were classified as undefined days; $30 \mathrm{~d}(15 \%)$ were non-event days, where no evidence of increasing particle concentration and growth has been noticed.
\end{abstract}

\section{Introduction}

Atmospheric nucleation events receive increasing attention as a potentially important source of aerosol particles affecting climate and human health (e.g. Charlson et al., 1987; Donaldson et al., 1998). In the last few decades, the climatological aspects of new particle formation are of great interest because of the incontestable effect of aerosol particles on the Earth's energy balance via direct and indirect effects (IPCC, 2007, http://www.ipccwg2.org/). The direct effect is due to scattering and absorption of solar and infrared radiation in the atmosphere, whereas the indirect effect is caused by changes in optical and physical properties of clouds. After its initial formation due to nucleation, an aerosol particle may grow to several hundreds of nanometres in diameter and act as a cloud condensation nucleus. Since Aitken $(1891,1897)$ first reported evidence for new particle formation in the atmosphere, new particle formation has been observed across the world in different environments (Kulmala et al., 2004a, and references cited therein).

\footnotetext{
* Corresponding author.

e-mail: larisa.sogacheva@ helsinki.fi

DOI: $10.1111 /$ j.1600-0889.2008.00364.x
}

Despite these abundant observations of new particle formation and growth, the mechanism remains largely unknown. Existing theories for this mechanism include binary watersulphuric acid nucleation theory (Kulmala and Laaksonen, 1990) and its improvement for tropospheric and stratospheric conditions (Vehkamäki et al., 2002), ternary water-sulphuric acidammonia nucleation theory (Napari et al., 2002; Merikanto et al., 2007), cluster activation theory (e.g. Kulmala et al., 2004b, 2006), Criegee intermediate reactions (Ryzhkov and Ariya, 2006) and reactions between biogenic stabilized Criegee intermediates and sulphuric acid (Kurtén et al., 2007). For the binary water-sulphuric acid system, Chan and Mohnen (1980) estimated a stable ion cluster distribution and a relative critical cluster population using the Thomson drop model. Modelling studies on ion-induced nucleation have been performed by Laakso et al. (2002). The role of ion clusters and different vapours in the growth of newly formed particles to detectable sizes has been studied, for example, by Kulmala et al. (2004c). Recently atmospheric nucleation and the effect on ions on it have been observed in Hyytiälä, Finland (Kulmala et al., 2007). Within this multitude of theories for new particle formation, several important factors affect nucleation, such as the chemical composition of the atmosphere, water content, and the amount 
of solar radiation. By investigating these effects on the formation of aerosol particles in the atmosphere, we hope to learn more about the processes that trigger new particle formation.

Several previous studies have investigated the effects of air masses and synoptic weather on aerosol particle formation at Hyytiälä, Southern Finland. During the BIOFOR 1, 2 and 3 campaigns, Buzorius et al. (2001) showed that large downward particle-number flux, intensive turbulent mixing in the vertical, strong net radiation and high sensible heat flux were observed during new particle formation. During the BIOFOR 3 campaign (11 March-30 April 1999), Nilsson et al. (2001a) reported that nucleation was favoured in Arctic, and, to some extent, Polar air masses. Nilsson and Kulmala (2006) expanded this analysis to $5 \mathrm{yr}$ of data corroborating that aerosol formation was most favoured in Arctic air. For an 8-yr period (1997-2003), Sogacheva et al. (2005a) used back trajectories to confirm that new particle formation occurs more frequently in air masses transported to Hyytiälä from over the Arctic and North Atlantic and to explain the results of long-term aerosol particle size distribution measurements as a consequence of air mass transport. Hellmuth (2006) investigated new particle formation and growth in a modelled convective boundary layer, confirming the conclusion of Hyvönen et al. (2005) that the probability of new particle formation is anticorrelated with the condensation sink, which determines how rapidly molecules condense onto pre-existing aerosols (Pirjola et al., 1999), and is anticorrelated with relative humidity.

Solar radiation, which regulates the intensity of photochemical reactions (and the formation of $\mathrm{OH}$ ) in the atmosphere, also plays an important role in aerosol particle formation (e.g. Clement et al., 2001; Boy and Kulmala, 2002a, b; Shupe and Intrieri, 2003). New particle formation is linked to the formation of $\mathrm{OH}$ radicals via photolysis (e.g. Berresheim et al., 2002; Arakaki et al., 2006). However, Nilsson et al. (2001b) showed that that the onset of turbulence in the morning hours was better correlated with the observation of new nanometre sized particles than the increase in UV-B was with the aerosol formation. This underlines the fact that fluctuations in radiation change not only photochemistry but also fundamental properties of the atmosphere that may in their turn influence particle formation even more than photochemistry. The amount of solar energy absorbed by the Earth depends, besides season and local time, on the fractional coverage and the optical properties of clouds. More clouds decrease the amount of radiation received by the Earth's surface, inhibiting new particle formation.

The purpose of this paper is to compare the synoptic conditions on days when new particles formed to days when particles did not form. Specifically, we examine the air masses, fronts, and cloudiness at Hyytiälä for the 3 yr 2003-2005, which include also other seasons than spring as investigated by Nilsson et al. (2001b). We compare how the air mass types and new particle formation events vary over the course of the year. Synoptic maps are also examined for the period of interest to classify the synoptic situation of each day. Finally, satellite images are analysed over Southern Finland to estimate the cloudiness conditions during nucleation events, undefined and non-event days. Having determined the favourable synoptic and cloudiness conditions for new particle formation at Hyytiälä, we analyse the days when at favourable conditions the formation of new particle does not happen. Using the monthly averaged cloudiness conditions we aim to explain the monthly distribution of the frequency of nucleation events occurring at Hyytiälä and year to year differences in the frequency of nucleation events during the spring, which is the period when nucleation occurs most often at Hyytiälä (Dal Maso et al., 2005).

\section{Methods}

The particle number concentration and size distribution were measured at the SMEAR II station at Hyytiälä, Southern Finland $\left(61^{\circ} 51^{\prime} \mathrm{N}, 24^{\circ} 17^{\prime} \mathrm{E}\right)$. The SMEAR II station is located $220 \mathrm{~km}$ northwest from Helsinki, $180 \mathrm{~m}$ above sea level in a homogenous Scots pine stand (Hari and Kulmala, 2005). Local pollution from the station buildings $(0.5 \mathrm{~km})$ and the city of Tampere $(60 \mathrm{~km})$, both located west-southwest from the station, occasionally affect the air quality at the SMEAR II station. Aerosol particle size distributions are measured with a Differential Mobility Particle Sizer (DMPS) system (Aalto et al., 2001), which consists of two Differential Mobility Analyzers (DMAs) producing overlapping size distributions and two Condensation Particle Counters (CPCs) to detect the selected particles. The system can observe particle sizes 3-600 $\mathrm{nm}$ in diameter with a time resolution of $10 \mathrm{~min}$.

A particle formation event is registered when a mode of fresh particles appears, manifested as a sudden increase in the number concentrations in the nucleation mode, with sizes less than $25 \mathrm{~nm}$ in diameter. In this work, we used the Hyytiälä event classification database. The classification method used in the creation of the database is based on the flowchart published in Dal Maso et al. (2005), which classifies a day into one of five classes: non-event, undefined or event (class Ia, Ib or II). In this study we applied these rules as follows. To classify as an event a day had to fulfil the following criteria: (1) particles smaller than $25 \mathrm{~nm}$ had to be present; (2) these particles had to form a mode that had not existed before; (3) this mode had to persist at least $1 \mathrm{~h}$ and (4) the particles in the new mode had to grow in size with time. Failure to fulfil the criteria (1), (2) and (3) resulted in a classification to the non-event class, and a failure to fulfil criterion (4) resulted in a classification to the undefined class. The classification was performed so that the probability of false positives for events was minimized, even if this would mean an increased amount of false negatives for events.

When a day was classified as an event day, it was further classified according to the possibility of further analysis. If it was possible to obtain the formation and growth rate of new particles, the day was classified as a class I event. For some 
days, while it was clear that the day was an event day, it was not possible to obtain these characteristics, due to for example strong fluctuations in the particle concentration. Such days were classified as class II events. Class Ia events are event days during which the new mode is clearly distinguishable from the preexisting particle population for the whole duration of the event, making these days good candidates for modelling case studies (Korhonen et al., 2004, Boy et al., 2006). On these days, the size distribution is dominated by the new particles. The rest of the class I events were classified as class Ib; it contains events during which the growing mode of new particles is at some time obscured by or superimposed to the pre-existing distribution.

To classify the types of the air masses arriving at Hyytiälä and the passages of the atmospheric fronts over Southern Finland, synoptic maps of the surface and $850-\mathrm{hPa}$ levels were examined from the Berliner Wetterkarte maps (http://www. berliner-wetterkarte.de/) from the German Weather Service (Deutscher Wetterdienst, DWD) together with the satellite images from the Advanced Very High Resolution Radiometer (AVHRR). The AVHRR is an imager (http://www2.ncdc.noaa. gov $/$ docs $/ \mathrm{klm} / \mathrm{html} / \mathrm{c} 3 / \mathrm{sec} 3-1$.htm) that can be used for determining cloud cover. Synoptic charts with a time resolution of $12 \mathrm{~h}$ were examined for the occurrence of fronts and for air mass classification in the lower troposphere (Bissolli and Dittmann, 2001). We used the air mass classification made daily at Berliner Wetterkarte for 0000 UTC. Local time at Hyytiälä is UTC plus $2 \mathrm{~h}$, and UTC plus $3 \mathrm{~h}$ during daylight savings time in the summer. The air mass classification recognizes Arctic, Polar and Subtropical air masses, each divided into marine, continental, and transition from marine to continental (those which lose moisture while travelling over the continent.) (Beilage zur Berliner Wetterkarte, http://www.met.fu-berlin.de/ $\sim$ manfred/luftmassen.html). Our approach was similar to that of Nilsson et al. (2001a), Birmili et al. (2001), Tunved et al. (2005) and Nilsson and Kulmala (2006), but we added much more details on the cloudiness and related this to the air masses and frontal systems.

The synoptic situation was classified according to the position of the surface atmospheric front passages over Southern Finland and specifically over Hyytiälä. All days have been divided into five groups (Table 1): no atmospheric fronts over Hyytiälä (group 1), 'prior to front' (group 2), 'under front' (group 3), 'after front' (group 4), several atmospheric fronts per day (group 5). Groups 2-4 have been divided into subgroups a, b and c with the respect to the type of the front: warm, cold, and occluded, respectively.

Fronts are defined as a change in air mass origin and may also be associated with changes in meteorological parameters such as temperature and relative humidity. Both of these may affect the aerosol properties (e.g. Van Eijk and De Leeuw, 1992). A warm front is the warm edge of a transition zone where an advancing warm air mass replaces a cold air mass (e.g. Locatelli and Hobbs, 1987; Hanesiak et al., 1997; Wakimoto and Bosart,
Table 1. Classification of synoptic situations at Hyytiälä with respect to atmospheric frontal passages

\begin{tabular}{lcll}
\hline Group & Frontal situation & Subgroup & Frontal situation \\
\hline 1 & No atmospheric fronts & & \\
2 & Prior to front & $2 \mathrm{a}$ & Prior to warm front \\
& & $2 \mathrm{~b}$ & Prior to cold front \\
& & $2 \mathrm{c}$ & Prior to occluded front \\
3 & Under front & $3 \mathrm{a}$ & Under warm front \\
& & $3 \mathrm{~b}$ & Under cold front \\
& & $3 \mathrm{c}$ & Under occluded front \\
4 & After front & $4 \mathrm{a}$ & After warm front \\
& & $4 \mathrm{~b}$ & After cold front \\
& & $4 \mathrm{c}$ & After occluded front \\
5 & & & \\
\hline
\end{tabular}

2001). Warm fronts generally move from southwest to northeast and the air behind a warm front is warmer and moister than the air ahead of it. A cold front is the warm edge of a transition zone where an advancing cold air mass replaces a warm air mass (e.g. Sanders, 1955; Schultz, 2005, 2008, and references therein). Cold fronts generally move from northwest to southeast. Behind a cold front, the air tends to be noticeably colder and drier than the air ahead of it. An occluded front (e.g. Schultz and Mass, 1993, and references therein) is formed during the process of cyclogenesis when a cold front overtakes a warm front. Synoptically, the pre-frontal environment of an occluded front resembles a warm front and the postfrontal environment resembles a cold front.

Because surface and 850-hPa level analyses were only available every $12 \mathrm{~h}$, the position of the atmospheric fronts on an hourly basis was defined more exactly using the satellite images (Bader et al., 1995, especially Sections 4 and 5) and groundbased measurements at the SMEAR II station (i.e. wind shift, temperature and relative humidity change). Although considerable variation existed from the satellite imagery, such imagery was useful for more precisely determining the timing of the frontal passage at Hyytiälä.

Cloudiness over Southern Finland was analysed from the AVHRR imagery in one of two time intervals. On event days, cloudiness was estimated for approximately $4 \mathrm{~h}$ around the event starting time, whereas, on non-event days, cloudiness was estimated in a time window 0800-1400 Local Time, which is the average start time of particle formation event at Hyytiälä (Dal Maso et al., 2005). However, when the event started at early morning or late evening, the time for estimation of the synoptic situation and cloudiness was chosen accordingly. Thus, the days were classified according to the sky cover for the selected time period into the following groups: clear sky, 1-2 octas (nearclear sky), 3-4 octas (isolated clouds), 5-6 octas (broken clouds), 7-8 octas (nearly unbroken cloudiness) and overcast (unbroken cloudiness). 


\section{Results and discussion}

No significant yearly differences in the frequency of the different types of air masses and atmospheric frontal passages were observed at Hyytiälä for 2003-2005. The results presented below are either cumulative frequency for 2003-2005 or fraction (in \%) for the same period of interest.

\subsection{Climatology of air-mass types at Hyytiälä}

The prevailing atmospheric currents in Scandinavia depend on the location of two quasi-stationary baric systems in the Northern Hemisphere: the Icelandic Low and Siberian High. Maritime air masses originate over the Arctic ice and are brought across the British Isles and surrounding waters by the air currents behind strong low pressure systems over Northern Europe. The occurrence of Arctic, Polar and Subtropical air masses at Hyytiälä has a clear annual cycle (Fig. 1).

Cold Arctic air masses are prevalent in the winter (40-50\% of the time during January-March), reaching a maximum in December (60\%) (Fig. 1a). The occurrence of Arctic air masses at Hyytiälä decreases strongly toward the summer and reaches its minimum in July (8\%).

The shape of the monthly distribution of Subtropical air masses is similar to the monthly frequency of the Polar air, although there are fewer Subtropical air masses. In contrast to Arctic air masses, Subtropical air masses are observed at Hyytiälä more often during the summer (22\% in July), when the quasi-stationary baric systems shift northward, allowing greater frequencies of incursions of the Subtropical air. The frequency of Subtropical air masses is very low in the winter $(<5 \%)$. In March, Subtropical air did not reach Hyytiälä during the observation period (Fig. 1a). The fraction of Polar air masses is about 55\% annually averaged, and the annual cycle of Polar air mass frequency is similar to the one of Subtropical air with the maximum (72\%) in July (Fig. 1a) because of the northward movement and weakening of the quasi-stationary baric systems in the summer.

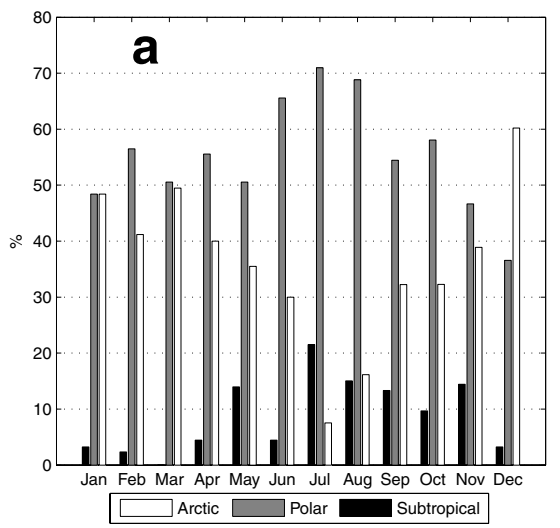

Marine air masses dominate at Hyytiälä every month except April and July, with maxima in September (77\%) and December (73\%) (Fig. 1b). In April, when the fraction of marine air masses is the lowest (31\%), continental air dominates (57\%). The transition air masses have a clear maximum in the winter, rarely occurring at Hyytiälä during the summer (Fig. 1b).

\subsection{Particle formation in different types of air masses}

The lack of anthropogenic pollution in Arctic air masses is believed to be one of the key factors that promote new aerosol particle formation (Nilsson et al., 2001a; Sogacheva et al., 2005a; Tunved et al., 2005; Nilsson and Kulmala, 2006). Law and Stohl (2007) showed that long-range transport of mid-latitude pollution could have a huge impact on trace gas and aerosol distribution in the Arctic. Such pollution changes the surface radiative forcing in the Arctic, may cause dramatic ozone depletion in the stratosphere, and is responsible for notable warming trends, which lead to the disappearance of summertime sea ice. In winter, less effective scavenging by snow compared to rain, dry deposition within the air mass and a strong transport pathway between Eurasian mid-latitudinal sources and the north, result in elevated levels of acidic anthropogenic aerosols and gases in the air mass. In summer, weak north-south transport and strong pollutant removal between the Arctic and mid-latitudes, as well as within the Arctic result in lower airborne concentrations of acidic pollutants (Barrie, 1986). Although the concentrations of $\mathrm{SO}_{2}$ and $\mathrm{NO}_{x}$ measured at Hyytiälä is generally low, increases within a short time period by local emissions and over a longer time period during eastern and southeastern transport can occur (Kulmala et al., 2000). Condensation sink, which also might be considered as an indicator of pollution, is lowest during transport from the northwest (Sogacheva et al., 2005b).

Averaged over the year, the strongest new particle formation (class Ia) occurs most often (71\%) in Arctic air masses (Fig. 2a). That result corresponds well to the important role of Arctic air masses in new particle formation (Birmili et al., 2001, Nilsson

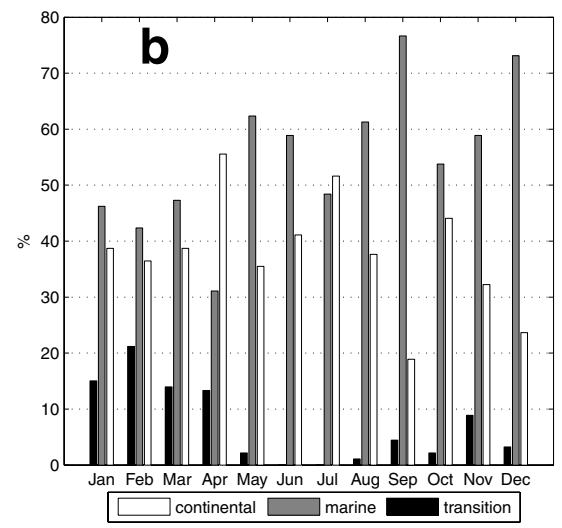

Fig. 1. Annual distribution of different types of air masses at Hyytiälä (a) Arctic, Polar, Subtropical air masses, (b) continental, marine, transition air masses. 

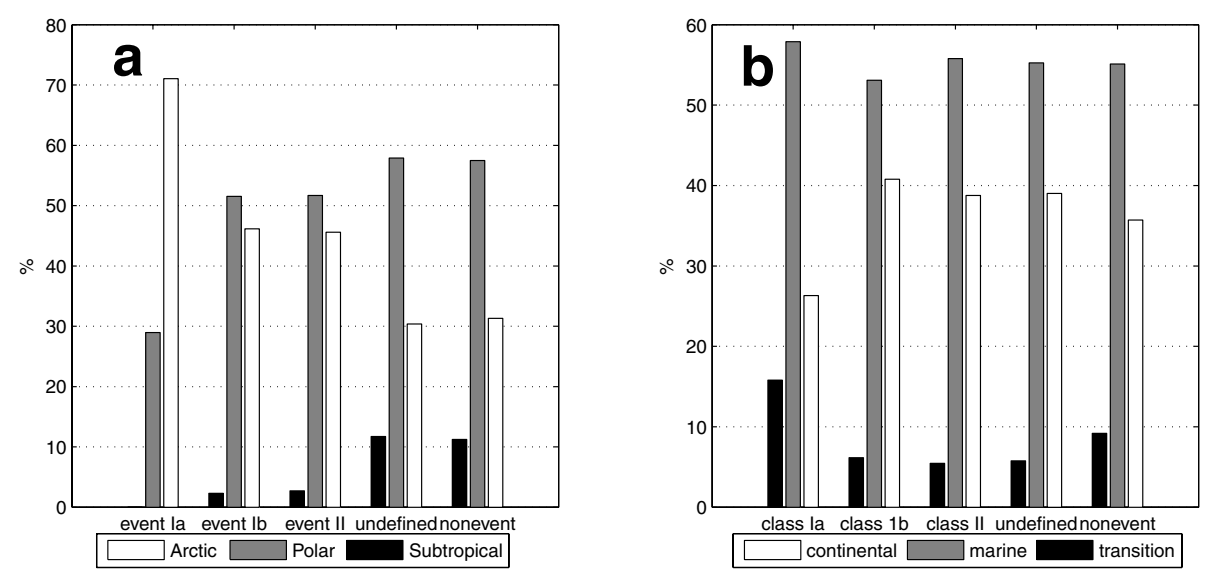

Fig. 2. Fraction of different types of air masses for days, classified according to a new particle formation (a) Arctic, Polar, Subtropical air masses, (b) continental, marine, transition air masses.

et al., 2001a; Sogacheva et al., 2005a; Tunved et al., 2005; Nilsson and Kulmala, 2006). Class Ia events have not been observed in Subtropical air masses.

Event classes Ib and II display nearly identical patterns of air masses during new particle formation (Fig. 2a), as confirmed by $t$-test. Specifically, about $51 \%$ of these two classes occur in Polar air masses and about $46 \%$ occur in Arctic air masses. Only about $3 \%$ of event classes Ib and II happen in Subtropical air masses. In contrast, the frequency of the different types of air masses is similar for the undefined and non-event days, where Polar air masses occurred at Hyytiälä on $58 \%$ of such days and Arctic air masses occurred on $31 \%$ of such days. The fraction of Subtropical air masses was highest (about 11\%) relative to the other classes. The difference between Ib/II and non-event/undefined groups of days is statistically significant.

There are no significant differences in the distributions of fractions of continental, marine, and transition air masses (39, 54 and $7 \%$ on average, respectively) for different classifications of new particle formation days, except for event class Ia days (Fig. 2b). The strongest new particle formation (class Ia) happens less often in continental air masses $(27 \%)$ compared to the other classes, whereas the fraction of transition air masses (16\%), which are originally marine air masses that lose moisture while travelling over the continent, is higher compared to the other classes.

\subsection{Climatology of frontal passages at Hyytiälä}

Monthly fractions of different types of synoptic situations at Hyytiälä during 2003-2005 are presented in Fig. 3. Most days had no frontal passages (40\% to more than $60 \%$ each month in April and December), with January being a maximum in frontal passages and several frontal passages in one day (12\%). Because the 'prior to front' group (group 2) is similar in different types of fronts (subgroups $2 \mathrm{a}, 2 \mathrm{~b}$ and $2 \mathrm{c}$ ) and nucleation does not happen in 'under front' conditions (subgroups $3 a, 3 b$ and $3 c$ ), we

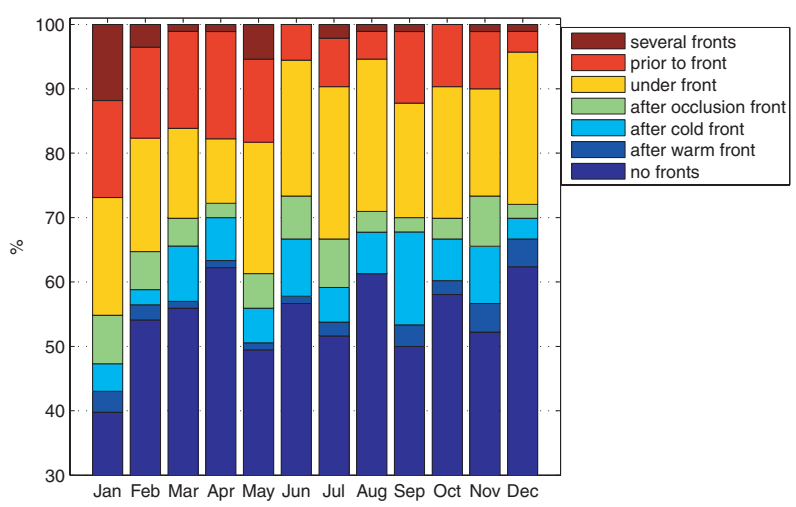

Fig. 3. Monthly fraction of different types of the synoptic situations at Hyytiälä with respect to atmospheric frontal passages.

combine the subgroups for these groups 2 and 3, respectively, retaining the division between warm, cold and occlusion front only for 'after front' situation (group 4). The fraction of 'prior to front' days was about $12 \%$ annually averaged, with highest frequency in winter and early spring. The 'under front' group was about $16 \%$ annually averaged with weak maxima (22\%) in July-August and December. The 'after front' conditions were observed at Hyytiälä on $15 \%$ of the days annually averaged with a maximum during late winter and early spring. $T$-test application shows significant differences in the monthly distribution of different synoptic situations.

\subsection{Particle formation relative to frontal passages}

Nilsson et al. (2001a) showed that, during the BIOFOR 3 campaign, class Ia and Ib nucleation events tended to be associated with cold-air outbreaks behind cold fronts and never occurred behind the warm front. Our analysis of class I and class II new particle formation events, performed for a much longer period (2003-2005) and throughout all seasons, confirms that conclusion and reveals other environmental conditions that affect the 


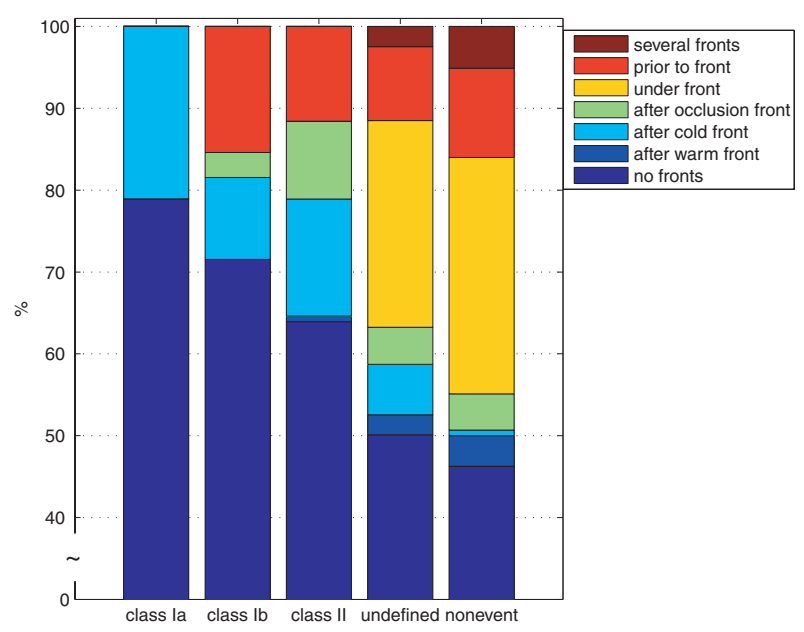

Fig. 4. Fraction of the different types of the synoptic situations classified according to atmospheric frontal passages for event days (class Ia, class Ib and class II), undefined and non-event days.

intensity and duration of particle formation events. In fact, this conclusion mirrors a similar result by Aitken (1897) who said 'When the wind is from the NW, the number of particles is always very low, $[\ldots]$ but $[\ldots]$ when the sun came out then numbers rapidly increased [...] to many thousands in the afternoon'.

The strongest nucleation events (class Ia) occur during two synoptic situations: when no frontal passages have been observed at Hyytiälä during the day $(78 \%$, or $30 \mathrm{~d})$ and after cold-frontal passages $(22 \%, 8 \mathrm{~d}$ ) (Fig. 4). The reason that no frontal passages and after cold-frontal passages are favoured for new particle formation is that these are conditions under which a change to an Arctic air mass is likely. In addition, such conditions also favour a lack of clouds and low relative humidity, conditions that are favourable for new particle formation. Weaker new particle formation events (classes Ib and II) also occur during those conditions (no frontal passages, 93 and $94 \mathrm{~d}$ and after cold-frontal passages, 13 and $21 \mathrm{~d}$, respectively for classes Ib and II) and 'prior to front' conditions, as well (20 cases in class Ib and 17 cases in class II). In 'prior to front' situations, if new particle formation happens, the growth of freshly formed particles is slower, whereas within a few hours after nucleation starts a frontal passage might bring clouds, precipitation or increase of relative humidity, and air mass changes - conditions which suppress the formation of the particles. 'After occlusion front' situations, which more often represents conditions, similar to post-cold-front conditions, are also favourable for class Ib and class II events (Fig. 4). Contrary to Nilsson et al. (2001a) who analysed class I events and never observed new particle formation during warm-air advection, we detected a few class II events after warm-frontal passages (Fig. 4), when Hyytiälä experienced a long time (more than one day) in the warm sector.

A considerable fraction of 'under front' situations (25\%, or 123 cases) occurs during undefined days (Fig. 4). 'Several fronts' situations (12 cases) for that group of days may explain why some of those days could not be classified either as event or nonevent days because the time between the frontal passages might not be enough to see a well-developed continuous formation event; however, an increase in particle concentration might be seen a few times during the day.

The fraction of 'prior to front', 'under front' and 'several fronts' situations (85, 32 and 15 cases, respectively) increases up to $45 \%$ for non-event days compared to the undefined days (Fig. 4). However, the fraction of 'no front' (136 cases) and 'after front' situations (27 cases) remains high for non-event days. Thus, the 'no fronts' situation is not a sufficient condition for particle formation and growth.

\subsection{Cloudiness and new particle formation}

To examine the role of incoming solar radiation on new particle formation, we computed the statistics of the occurrence of new particle formation under varying amounts of cloud cover. More than $90 \%$ of the class Ia events occurred at Hyytiälä under clear-sky or nearly clear-sky (1-2 octas) conditions (Fig. 5). For the rest of the class Ia events, cloudiness at Hyytiälä was lower than 5 octas (less than half of the sky was covered by clouds). Hereinafter, we call days with cloudiness higher than 4 octas as 'high-cloud-amount' days and cloudiness less than 5 octas 'low-cloud-amount' days. Those results are in agreement with the cloudiness analysis made by Charron et al. (2007) for 26 large-scale episodes of new particle formation observed at a rural site in Southern England.

Because class Ia events have not occurred at Hyytiälä during 2003-2005 during high-cloud-amount days, we consider the low-cloud-amount days as a potential indicator of when a well-defined new particle formation event might occur. However, less robust nucleation could happen on high-cloud-amount days. Specifically, about $7 \%$ of class Ib events and $27 \%$ of class II events occurred when more than half of the sky was

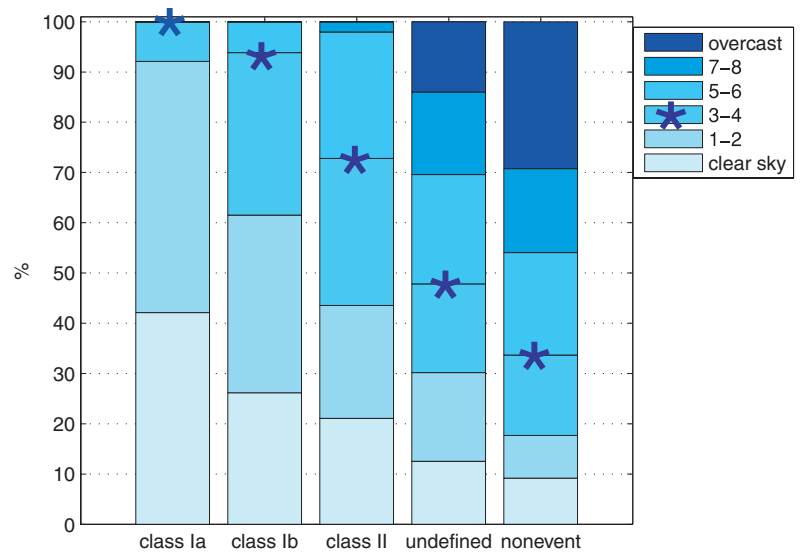

Fig. 5. Cloudiness (color, in octas) for event days (class Ia, class Ib, class II), undefined and non-event days. Blue star is a border between 3-4 octas (isolated clouds) and 5-6 octas (broken clouds) cloudiness. 
covered by clouds (Fig. 5). From this follows that high-cloudamount, even though it cannot completely prevent an aerosol formation, is an important parameter in explaining why a formation case becomes a Ib or II instead of Ia. This supports and adds significantly more details to the conclusions by Nilsson et al. (2001a) to the comparison of aerosol formation and cloudiness.

Note that nearly clear-sky (1-2 octas) to isolated clouds (34 octas) conditions were as favourable for aerosol formation as clear skies, see Fig. 5. These cases corresponds to 'fair weather conditions', the broken cloud cover often formed behind cold fronts and hence corresponds directly to the results shown in Fig. 4.

The fraction of high-cloud-amount days increases for undefined and non-event days (52 and 66\%, respectively) (Fig. 5). Therefore, in about half of the undefined days, the cloud conditions were favourable for new particle formation and $18 \%$ of non-event days were low-cloud-amount days. Thus, because there are many low-cloud-amount days with no new particle formation (either classified as undefined or non-events days), low-cloud-amount days alone are not sufficient for new particle formation. Hence, other factors may also be limiting a new aerosol particle formation even at favourable cloud conditions.

In summary, the most favourable conditions for robust new particle formation (class Ia) at Hyytiälä, Southern Finland, occurs in (1) Arctic air masses, (2) when no frontal passages have been observed at Hyytiälä, or after cold-frontal passage and (3) when cloudiness at Hyytiälä is not higher than 4 octas. During 2003-2005, $198 \mathrm{~d}$ (18\%) satisfy all three conditions. For $105(57 \%)$ of those $198 \mathrm{~d}$, new particle formation was observed at Hyytiälä. In contrast, $53 \mathrm{~d}(28 \%)$ were classified as undefined days, and only $30 \mathrm{~d}(15 \%)$ were non-event days, where no evidence of increasing particle concentration and growth has been noticed. These results indicate that, despite having identified favourable synoptic conditions for new particle formation, the complete conditions for new particle formation remain unknown.

\section{Why does nucleation not happen all the time with favourable synoptic and cloudiness conditions?}

Among the days with synoptic and cloudiness conditions favourable for new particle formation, $30 \mathrm{~d}$ have been classified as non-event days. To answer why nucleation does not occur although synoptic and cloudiness conditions are favourable we analysed meteorological conditions, gas concentrations and condensation sink, which is the indicator of the amount of preexisting particles, for those non-event days.

Previous results in Section 3 concluded 'no fronts' and 'after cold front' conditions are the most favourable synoptic conditions for new particle formation (Fig. 4). However, all 30 nonevent days were classified as 'no fronts' conditions suggesting some hitherto unknown factor may be responsible for new particle formation in 'after cold front' conditions.

Of these 30 non-event days $90 \%$ (27 d) were observed in winter time. About $47 \%$ (14 d) of those winter days are days with a less then maximum $80 \mathrm{Wm}^{-2}$ of global radiation, associated with the short winter days at high latitudes, even when cloudiness was less than 4 octas. Cloudiness of 3-4 octas, which is close to the upper limit favourable for new particle formation, has been observed in $50 \%$ ( $15 \mathrm{~d}$ ) of the selected days.

Another reason for suppression of nucleation during days with favourable synoptic and cloudiness conditions is a high pollution level explaining 53\% (16 d) of the non-event days. In $63 \%$ (19 d) of 30 cases, high condensation sink (daily median value higher than $2.5 \times 10^{-2} \mathrm{~cm}^{-3} \mathrm{c}^{-1}$ ), which can be considered as an indicator of pre-existing particles suppressing the formation of nucleation mode particles, has been observed in Hyytiälä. High background levels of Aitken mode particles (25-90 nm) have been observed in $33 \%$ of days.

In summary, the lack of new particle formation in 28 of $30 \mathrm{~d}$ (93\%) with favourable synoptic and cloudiness conditions can be explained by either the low level of radiation during the short daylight hours, or a high pollution level with a high concentration of pre-existing particles (i.e. high condensation sink), or by the combination of those factors. However, for the two remaining days (21 and 22 of January 2004) another explanation for the lack of new particle formation has to be found. Among them is high relative humidity, observed during those days, which according to Hyvönen et al. (2005) can also inhibit the formation of new particles. Thus, we confirm the conclusion (e.g. Väkevä et al., 2000; Birmili et al., 2003; Uhrer et al., 2003; Lyubovtseva et al., 2005; Sogacheva et al., 2005a; Lunden et al., 2006) that both meteorology and pollutant concentrations are important characteristics that influence new particle formation.

\section{Cloudiness and nucleation event frequency}

The monthly distribution of cloudiness, event days, and nonevent days is presented in Fig. 6. During 2003-2005, the maximum of low-cloud-amount days occurred in March and April (73 and $63 \mathrm{~d}$, respectively), with a less pronounced maximum (58 d) in September (Fig. 6). Those maxima correspond well to the maxima in monthly cumulative number of new particle formation events observed at Hyytiälä (Fig. 6). Thus, cloudiness at Hyytiälä might be used to explain the frequency of nucleation events at Hyytiälä.

Using cloudiness data for Southern Finland, we aimed to explain the annual frequency of new particle formation events at Hyytiälä (Dal Maso et al., 2005). During 2003-2005, the number of events at Hyytiälä has been gradually decreasing (Fig. 7a). However, the gradual decrease is not seen in the number of lowcloud-amount days. The reason for that can be explained by the monthly distributions of cloudiness and event classifications calculated separately for 2003, 2004 and 2005 (Fig. 8). In January 


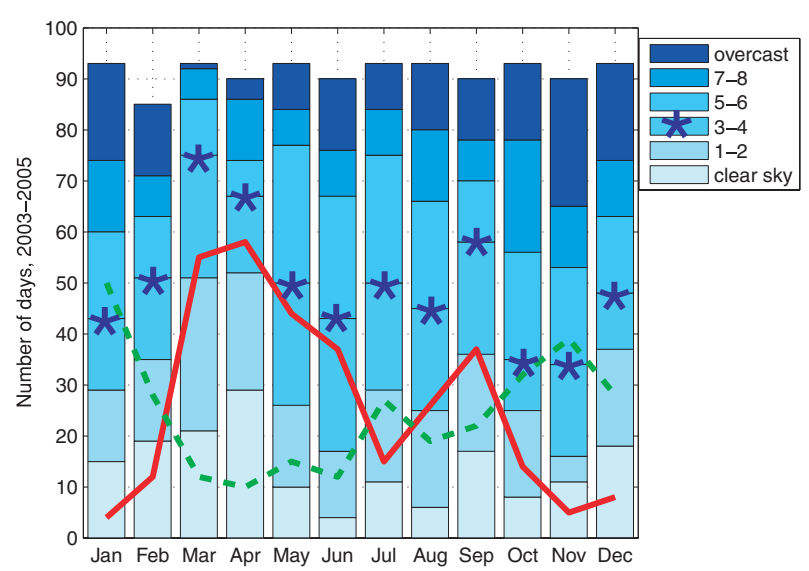

Fig. 6. Annual distribution of cloudiness (colorbar, in octas), event (red line) and non-event (green line) days at Hyytiälä. Blue star is a border between 3-4 octas (isolated clouds) and 5-6 octas (broken clouds) cloudiness.

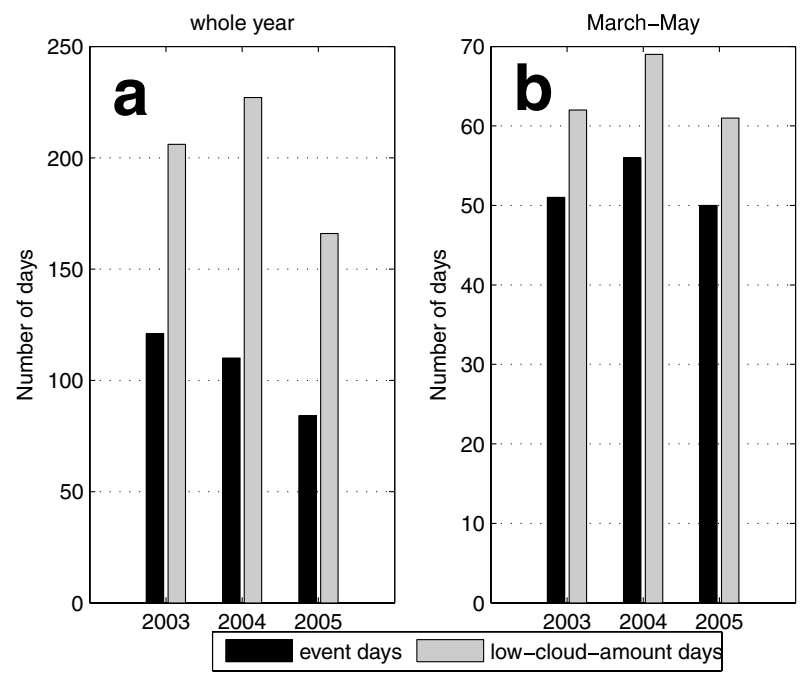

Fig. 7. Yearly number of event days and number of low-cloud-amount days for years 2003, 2004 and 2005 (a), and the same for months March-May (b).

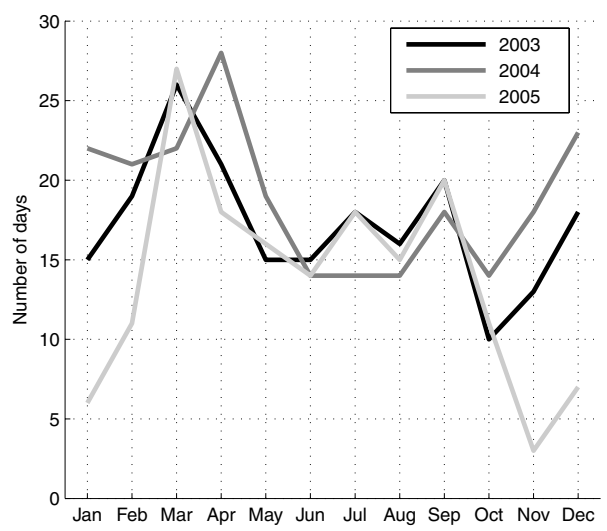

Fig. 8. Monthly frequency of low-cloud-amount days for years 2003, 2004 and 2005 at Hyytiälä. and during the period October to December 2004, the number of low-cloud-amount days was considerably higher, compared to the same period in 2003 and 2005. However, the main reason for the low number of event days during that period is the monthly minimum of solar radiation at Hyytiälä. Thus, during late autumn and early winter, cloudiness cannot be considered as an indicator of a nucleation event.

However, our hypothesis on the relation of monthly number of event days to the monthly number of low-cloud-amount days works well in spring when new particle formation is observed more often (Fig. 7b). The increase of events in spring 2004 can be explained by the increase in low-cloud-amount days during that period compared to the other years.

\section{Conclusions}

In this paper the connections between synoptic weather conditions and new particle formation events have been investigated. The main new results beyond earlier ones (e.g. Nilsson et al., 2001a) are (1) cloudiness has been analysed for a 3-yr period and connected to events classification (see Fig. 5), (2) seasonality in events in Hyytiälä can be explained by the seasonal distribution of low-cloud-amount days (see Fig. 6) and (3) year-to-year differences in the nucleation events frequency can be explained by year-to-year difference in low-cloud-amount days (see Fig. 7).

Arctic air masses are observed at Hyytiälä more often in winter, reaching a maximum in December, but sustaining high frequency well into the spring. In about half of the days, Polar air masses prevail at Hyytiälä. Subtropical air has its highest frequency in midsummer. Marine air masses prevail at Hyytiälä throughout the year, except for April. Continental air is distributed evenly throughout the year. Transition air masses are more frequent in winter and have not been observed in June and July.

The strongest new particle formation (event class Ia) occurs more often in Arctic air, but not in Subtropical air masses. The fraction of Arctic and Polar air in class Ib and class II events is comparable with a small dominance of Polar air masses; in a few cases, event classes Ib and II have occurred in Subtropical air masses. The distribution of air mass frequency is similar for undefined and non-event days and occurs in the ratio 6:3:1 for Arctic, Polar and Subtropical air, respectively. No significant differences have been revealed in the character of the air mass (marine, continental and transition) with respect to new particle formation except for class Ia, for which the fraction of transition air masses is higher comparing to other days.

During about half of the days no frontal passages have been observed at Hyytiälä. Frontal passages have been observed more frequently in January, gradually decreasing in spring.

The most favourable situation for new particle formation is after cold-frontal passages, and the following days until the next front reaches Hyytiälä ('no fronts' in our classification). New particle formation event classes Ib and II occur before fronts as 
well; however, in these cases, the growth of the particles slows down as the frontal cloudiness develops and particles never grow as much and as fast as during class Ia events. Several frontal passages and slow-moving fronts are observed at Hyytiälä often during undefined and non-event days.

Class Ia events are registered at Hyytiälä under clear skies or low-cloud-amount (1-2 octas) conditions. The fraction of days with 3-4 octas cloudiness becomes rather significant in class Ib events; class II events rarely occur at 7-8 octas cloudiness. We consider cloudiness less than 5 octas as one of the necessary conditions for new particle formation; however, at higher cloud amounts, class Ib and class II events may occur. Cloudiness above 4 octas appears to be a key factor for turning an aerosol formation event into class Ib and class II and preventing Ia case.

The monthly cumulative number of nucleation events for 2003-2005 corresponds well to the cumulative number of the days with cloudiness 3-4 octas and lower for the same period. March-April and September maxima in new particle formation are seen in the number of low cloudiness days for the corresponding months.

The smaller number of nucleation events in year 2005 with respect to year 2003 can be explained by the lower occurrence of the clear sky and low-cloud-amount days. The high number of low-cloud-amount days in the winter, when particle formation occurrence is low, for the year 2004 explains the discrepancy in our assumption on the yearly correspondence of the number of nucleation days to the number of low cloudiness days. During the period of the most frequent new particle formation (MarchMay), the correspondence of the number of nucleation days to the number of low-cloud-amount days is similar.

\section{Acknowledgment}

This work was supported by the Academy of Finland and the Nordic Center of Excellence BACCI.

\section{References}

Aalto, P., Hämeri, K., Becker, E., Weber, R., Salm, J., and co-authors. 2001. Physical characterization of aerosol particles during nucleation events. Tellus 53B, 344-358.

Aitken, J. 1891. On dust, fog and clouds. Nature 23, 195-197.

Aitken, J. A. 1897. On some nuclei of cloudy condensation. Trans. Roy. Soc. XXXIX, 15-25.

Arakaki, T., Kuroki, Y., Okada, K., Nakama, Y., Ikota, Y., and co-authors. 2006. Chemical composition and photochemical formation of hydroxyl radicals in aqueous extracts of aerosol particles collected in Okinawa, Japan. Atmos. Envir. 40(25), 4764-4777.

Bader, M. J., Forbes, G. S., Grant, G. R., Lilley, R. B. E. and Waters A. J. 1995. Images in Weather Forecasting. Cambridge University Press, NY, USA 500p.

Barrie, L. A. 1986. Background pollution in the Arctic air mass and its relevance to North American acid rain studies. Water, Air Soil Pollut. 30, 762-777.
Berresheim, H., Elste, T., Tremmel, H. G., Allen, A. G., Hansson, H.-C., and co-authors. 2002. Gas-aerosol relationships of $\mathrm{H}_{2} \mathrm{SO}_{4}$, MSA and $\mathrm{OH}$ : observations in the coastal marine boundary layer at Mace Head, Ireland. J. Geophys. Res. 107(D19), 8100, doi:10.1029/ 2000JD000229.

Birmili, W., Wiedensohler, A., Heintzenberg, J. and Lehmann, K. 2001. Atmospheric particle number size distribution in central Europe: statistical relations to air masses and meteorology. J. Geophys. Res. 106, 32005-32018.

Birmili, W., Berresheim, H., Plass-Dülmer, C., Elste, T., Gilge, S., and co-authors. 2003. The Hohenpeisenberg aerosol formation experiment (HAFEX): a long-term study including size-resolved aerosol, H2SO4, $\mathrm{OH}$ and monoterpenes measurements. Atmos. Chem. Phys. 3, 361376.

Bissolli, P. and Dittmann, E. 2001. The objective weather type classification of the German Weather Service and its possibilities of application to environmental and meteorological investigations. Met. Zeitschrift 10(4), 253-260.

Boy, M. and Kulmala, M. 2002a. Nucleation events in the continental boundary layer: influence of physical and meteorological parameters. Atmos. Chem. Phys. 2, 1-16.

Boy, M. and Kulmala, M. 2002b. The part of solar spectrum with the highest influence on the formation of SOA in the continental boundary layer. Atmos. Chem. Phys. 2, 375-386.

Boy, M., Hellmuth, O., Korhonen, H., Nilsson, D., ReVelle, D., and co-authors. 2006. MALTE-model to predict new aerosol formation in the lower troposphere. Atmos. Chem. Phys. 6, 44994517.

Buzorius, G., Rannik, Ü., Nilsson, D. and Kulmala, M. 2001. Vertical fluxes and micrometeorology during aerosol particle formation events. Tellus 53B, 394-405.

Chan, L. Y. and Mohnen, V. A. 1980. The formation of ultrafine ion $\mathrm{H}_{2} \mathrm{O}-\mathrm{H}_{2} \mathrm{SO}_{4}$ aerosol particle through ion-induced nucleation process in the stratosphere J. Aeros. Sci. 11, 35-45.

Charlson, R. J., Lovelock, J. E., Andreae, M. O. and Warren, S. G. 1987. Oceanic phytoplankton, atmospheric sulphur, cloud albedo and climate. Nature 326, 655-661.

Charron, A., Birmilli, W. and Harrison, R. M. 2007. Factors influencing new particle formation at the rural site, Harwell, United Kingdom. $J$. Geophys. Res. 112, D14210, doi:10.1029/2007JD008425.

Clement, C. F., Pirjola, L., Dal Maso, M., Mäkelä, J. M. and Kulmala, M. 2001. Analysis of particle formation bursts observed in Finland. J. Aeros. Sci. 32, 217-236.

Dal Maso, M., Kulmala, M., Riipinen, I., Wagner, R., Hussein, T., and coauthors. 2005. Formation and growth of fresh atmospheric aerosols: eight years of aerosol size distribution data from SMEAR II, Hyytiälä, Finland. Boreal Env. Res. 10, 323-336.

Donaldson, K., Li, X. Y. and MacNee, W. 1998. Ultrafine (nanometer) particle-mediated lung injury. J. Aerosol. Sci. 29, 553-560.

Hanesiak, J. M., Stewart, R. E., Szeto, K. K., Hudak, D. R. and Leighton, H. G. 1997. The structure, water budget, and radiational features of a high-latitude warm front. J. Atmos. Sci. 54, 1553-1573.

Hari, P. and Kulmala, M. 2005. Station for Measuring EcosystemAtmosphere Relations (SMEAR II). Boreal Environ. Res. 10, 315322.

Hellmuth, O. 2006. Columnar modeling of nucleation burst evolution in convective boundary layer-first results from feasibility study. Parts I-IV. Atmos. Chem. Phys. 6, 4175-4274. 
Hyvönen, S., Junninen, H., Laakso, L., Dal Maso, M., Grönholm, T., and co-authors. 2005. A look at aerosol formation using data mining technique. Atmos. Chem. Phys. 5, 3345-3356.

Korhonen, H., Lehtinen, K. E. J. and Kulmala, M. 2004. Multicomponent aerosol dynamics model UHMA: model development and validation. Atmos. Chem. Phys. 4, 757-771.

Kulmala, M. and Laaksonen, A. 1990. Binary nucleation of watersulfuric acid system: comparison of classical theories with different $\mathrm{H}_{2} \mathrm{SO}_{4}$ saturation vapor pressures. J. Chem. Phys. 93, 696-701.

Kulmala M., Rannik, Ü., Pirjola, L., Dal Maso, M., Karimäki J., and coauthors. 2000. Characterization of atmospheric trace gas and aerosol concentrations at forest sites in southern and northern Finland using back trajectories. Boreal Environ. Res. 5, 315-336.

Kulmala, M., Vehkamäki, H., Petäjä, T., Dal Maso, M., Lauri, A., and coauthors. 2004a. Formation and growth rates of ultrafine atmospheric particles: a review of observations. J. Aerosol. Sci. 35, 143-176.

Kulmala, M., Kerminen V.-M., Antttila, T., Laaksonen, A. and O'Dowd, C. 2004b. Organic aerosol formation via sulphate cluster activation. J. Geophys. Res. 109, D04205, doi:10.1029/2003JD003961.

Kulmala, M., Laakso, L., Lehtinen, K. E. J., Dal Maso, M., Anttila, T., and co-authors. 2004c. Initial steps of aerosol growth. Atmos. Chem. Phys. 4, 2553-2560.

Kulmala, M., Lehtinen, K. E. J. and Laaksonen, A. 2006. Cluster activation theory as an explanation of the linear dependence between formation rate of $3 \mathrm{~nm}$ particles and sulphuric acid concentration. Atmos. Chem. Phys. 6, 787-793.

Kulmala, M., Riipinen, I., Sipilä, M., Manninen, H., Petäjä, T., and co-authors. 2007. Towards direct measurement of atmospheric nucleation. Science 318, 89-92, doi:10.1126/science.1144124.

Kurtén, T., Bonn, B., Vehkamäki, H. and Kulmala, M. 2007. Computational studies of the reactions between biogenic stabilized Criegee intermediates and sulphyric acid. J. Phys. Chem. A 111, 3394-3401.

Laakso, L., Mäkelä, J. M., Pirjola, L. and Kulmala, M. 2002. Model studies on ion-induced nucleation in the atmosphere. J. Geophys. Res. 107(D20), 4427, doi:10.1029/2002JD002140.

Law, K. and Stohl, A. 2007. Arctic air pollution: origin and impacts. Science 315, 1537-1540.

Locatelli, J. D. and Hobbs, P. V. 1987. The mesoscale and microscale structure and organization of clouds and precipitation in midlatitude cyclones. XIII: structure of a warm front. J. Atmos. Sci. 44, 22902309.

Lunden, M. M., Black, D. R., McKay, M., Revzan, K. L., Goldstein, A. H., and co-authors. 2006. Characteristics if fine psrticle growth events observed above forest ecosystems in the Sierra Nevada Mountains of California. Aerosol Sci. Tech. 40, 373-388.

Lyubovtseva Yu., Sogacheva L., Dal Maso, M., Bonn B., Keronen P., and co-authors. 2005. Seasonal variations of trace gases, meteorological parameters, and formation of aerosols in boreal forests. Boreal Environ. Res. 10: 493-510.

Merikanto, J., Napari, I., Vehkamäki, H., Anttila, T. and Kulmala, M. 2007. New parameterization of sulfuric acid-ammonia-water ternary nucleation rates at tropospheric conditions. J. Geophys. Res. 112, D15207, doi:10.1029/2006JD007977.

Napari, I., Noppel, M., Vehkamäki, H. and Kulmala, M. 2002. Parameterization of ternary nucleation rates for $\mathrm{H}_{2} \mathrm{SO}_{4}-\mathrm{NH}_{3}-\mathrm{H}_{2} \mathrm{O}$ vapors. $J$. Geophys. Res. 107(D19), 4381, doi:10.1029/2002JD002132.

Nilsson, E. D. and Kulmala, M. 2006. Aerosol formation over the Boreal forest at Hyytiälä, Finland: monthly frequency and annual cyclesthe roles of air mass characteristics and synoptic scale meteorology. Atmos. Chem. Phys. Discuss. 6, 10425-10462.

Nilsson E. D., Paatero J. and Boy, M. 2001a. Effect of air masses and synoptic weather on aerosol formation in the continental boundary layer. Tellus 53B, 462-478.

Nilsson, E. D., Rannik, Ü., Buzorius, G., Kulmala, M. and O'Dowd, C. 2001b. Effects of the continental boundary layer evolution, convection, turbulence and entrainment on aerosol formation. Tellus 53B, 441-461.

Pirjola, L., Kulmala, M., Wilck, M., Bischoff, A., Stratmann, F., and co-authors. 1999. Effects of aerosol dynamics on the formation of the sulphuric acids aerosols and cloud condensation nuclei. J. Aerosol Sci. 30, 1079-1094.

Ryzhkov, A. B. and Ariya, P. A. 2006. The importance of water clusters $(\mathrm{H} 2 \mathrm{O}) \mathrm{n}(\mathrm{n}=2.4)$ in the reaction of Criegee intermediate with water in the atmosphere. Chem. Phys. Lett. 419, 479-485.

Sanders, F. 1955. An investigation of the structure and dynamics of an intense surface frontal zone. J. Meteor. 12, 542-552.

Schultz, D. M. 2005. A review of cold fronts with prefrontal troughs and wind shifts. Mon. Wea. Rev. 133, 2449-2472.

Schultz, D. M. 2008. Perspectives on Fred Sanders's research on cold fronts. The Fred Sanders Symposium Volume, Meteor. Monogr., Amer. Meteor. Soc., in press.

Schultz, D. M. and C. F. Mass 1993. The occlusion process in a midlatitude cyclone over land. Mon. Wea. Rev. 121, 918-940.

Shupe, M. D. and Intrieri, J. M. 2003. Cloud radiative forcing of the arctic surface: the influence of cloud properties, surface Albedo, and Solar Zenith Angle. J. Clim. 17, 616-628.

Sogacheva, L., Dal Maso, M., Kerminen, V.-M. and Kulmala M. 2005a. Probability of nucleation events and aerosol particle concentration in different air mass types arriving at Hyytiälä, southern Finland, based on back trajectory analysis. Boreal Environ. Res. 10, 479-491.

Sogacheva, L., Dal Maso, M. and Kulmala, M. 2005b. Aerosol particle number concentration and condensation sink study in Hyytiälä, southern Finland using back trajectory analysis. Second Joint BACCI Meeting, Kuopio, Finland, 102-105.

Tunved, P., Nilsson, E. D., Hansson, H.-C., Ström, J., Kulmala, M., and co-authors. 2005. Aerosol characteristics of air masses in northern Europe: influences of location, transport, sinks, and sources. J. Geophys. Res. 110, D07201, doi:10.1029/2004JD005085.

Uhrer, U., Birmili, W., Stratmann, F., Wilck, W., Ackermann, I. J., and co-authors. 2003. Particle formation at a continental background site: comparison of model results with observations. Atmos. Chem. Phys. 3, 347-359.

Van Eijk, A. M. J. and de Leeuw, G. 1992. Modeling aerosol particle size distributions over the North Sea. J. Geophys. Res. 97, 14417-14429.

Vehkamäki, H., Kulmala, M., Napari, I., Lehtinen, K. E. J., Timmreck, C., and co-authors. 2002. An improved parameterization for sulfuric acid/water nucleation rates for tropospheric and stratospheric conditions. J. Geophys. Res. 107(D22), 4622, doi:10.1029/2002JD002184.

Väkevä, M., Hämeri, K., Puhakka, T., Nilsson, E. D., Hohti, H., and co-authors. 2000. Effects of meteorological processes on aerosol particle size distribution in an urban background area. J. Geophys. Res. 105(D8), 9807-9821.

Wakimoto, R. M. and B. L. Bosart. 2001. Airborne radar observations of a warm front during FASTEX. Mon. Wea. Rev. 129, 254-274. 